\title{
Shiga Toxin-Producing E. Coli 0104:H4 Outbreak 2011 in Germany: Radiological Features of Entero- hemorrhagic Colitis
}

\author{
Radiologische Merkmale der enterohämorrhagischen Kolitis beim EHEC- \\ Ausbruch 2011 des enteroaggregativen E.-coli-Stammes 0104:H4
}

Authors

Affiliations

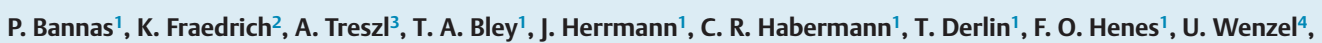
G. Adam 1 , J. Yamamura ${ }^{1}$

Affiliation addresses are listed at the end of the article.

\section{Key words}

- hemolytic-uremic syndrome

- conventional radiography

- CT

Shiga toxin-producing E. coli

- 0104:H4

- enterohemorrhagic colitis

eingereicht 10.9 .2012

akzeptiert 12.12.2012

Bibliography

Dol http://dx.doi.org/

10.1055/s-0032-1330520

Published online: 25.2 .2013

Fortschr Röntgenstr 2013; 185 :

434-439 ๑ Georg Thieme

Verlag KG Stuttgart · New York . ISSN 1438-9029

\section{Correspondence \\ Dr. Peter Bannas \\ Diagnostikzentrum, Klinik und \\ Poliklinik für Diagnostische und Interventionelle Radiologie, \\ Universitätsklinikum Hamburg- Eppendorf \\ Martinistraße 52 \\ 20246 Hamburg \\ Germany \\ P.bannas@uke.de \\ Tel.: ++ 49/40/741054023 \\ Fax: ++49/40/74106799}

\section{Zusammenfassung \\ $\nabla$}

Ziel: Im Jahre 2011 kam es in Deutschland landesweit zu Erkrankungsfällen mit dem hämolytischurämischen Syndrom (HUS) und blutigen Durchfällen bei einer Infektion durch Enterohämorrhagische Escherichia coli (EHEC) des Serotyps 0104: H4.Ziel war es, die radiologischen Merkmale dieser Patienten zu bestimmen und mit klinischen Parametern zu korrelieren.

Material und Methoden: 23 Patienten (7 Männer; Alter: $48 \pm 19$ Jahre) mit 0104:H4-Kolitis und/oder HUS wurden mittels CT $(n=12)$ oder Abdomenübersichtsaufnahme ( $n=11)$ untersucht. Alle 23 Untersuchungen wurden retrospektiv hinsichtlich Kolondistension, Luft-Flüssigkeitsspiegeln und freier intraabdomineller Luft beurteilt. Im CT wurde zusätzlich Kolonwanddicke, Kontrastmittelanreicherung, perikolische Fettgewebsimbibierung sowie Aszitesmenge bestimmt. Laborparameter und klinische Untersuchungsmerkmale wurden notiert. Chi-Quadrat-Test, t-Test, McNemar-Test sowie Spearman-Korrelation wurden durchgeführt um die Daten zu analysieren.

Ergebnisse: Eine Kolondistension wurde bei 16/23 Patienten (69,6\%) beobachtet. Das aszendierende (11/23 Patienten; 47,8\%) und transversale Kolon (12/23 Patienten; 52,2\%) waren signifikant öfter dilatiert ( $\mathrm{p}=0,006$ bzw. $\mathrm{p}=0,003$ ) als das deszendierende Kolon (1/23; 4,3\%). Alle 12 CT-Patienten zeigten abnormal wandverdickte Kolonsegmente, 3 (25\%) davon hatten eine Pankolitis und 9 Patienten (75\%) hatten eine segmentale Beteiligung. Das deszendierende Kolon war überwiegend (11/12 Patienten; $91.7 \%)$ und signifikant häufiger ( $p<0,001)$ als die anderen Kolonsegmente betroffen.

Schlussfolgerungen: Bei der STEC-0104:H4-Kolitis findet sich vornehmlich ein segmentaler Befall des deszendierenden Kolons mit vorgeschalteter Dilatation des transversalen und aszendierenden Kolons, wodurch sich dieser Typ der Kolitis möglicherweise von anderen Kolitiden unterscheidet.

\section{Abstract \\ $\nabla$}

Purpose: In 2011 a nationwide outbreak of Shiga toxin-producing E. coli (STEC) 0104:H4 infection occurred in Germany with severe hemorrhagic colitis and hemolytic-uremic syndrome (HUS). We defined abdominal radiologic findings in these patients and correlated them with clinical parameters.

Materials and Methods: 23 patients ( 7 men; age: $48 \pm 19$ years) with 0104:H4 colitis and/or HUS received abdominal CT $(n=12)$ or radiographs $(\mathrm{n}=11)$. Colonic distension, air-fluid levels, and free intraabdominal air were assessed. Colonic wall thickening, contrast enhancement, pericolic stranding, and ascites were evaluated on CT. Laboratory parameters and clinical presentation were reviewed. Chi-square test, Student's t-test, McNemar's test and Spearman correlation were performed.

Results: Colonic lumen distension was seen in $16 / 23$ patients (69.6\%). The ascending colon (11/23 patients; $47.8 \%)$ and transverse colon (12/23 patients; $52.2 \%$ ) were dilated significantly more often $(\mathrm{p}=0.006$ and $\mathrm{p}=0.003$, respectively) than the descending colon $(1 / 23 ; 4.3 \%)$. All 12 patients undergoing CT scanning had abnormally thickened colonic wall segments, 3 (25\%) had pancolic involvement and 9 (75\%) had segmental involvement. The descending colon was predominantly affected (11/12 patients; $91.7 \%$ ) and thickened significantly more often than other colonic segments ( $\mathrm{p}<0.001)$.

Conclusion: The segmental type of STEC 0104:H4 colitis mainly affects the descending colon with upstream distension of the transverse/ascending colon and differs from other types of colitis. 


\section{Introduction}

\section{$\nabla$}

Escherichia coli is a widespread commensal of the mammalian gut and a versatile pathogen [1]. Certain strains of enterohemorrhagic E. coli produce Shiga toxin which inhibits protein synthesis within susceptible eukaryotic cells leading to colitis. Infected patients characteristically have an afebrile illness that begins with abdominal cramps and watery diarrhea, which progresses to bloody diarrhea with high morbidity and mortality $[1,2]$. Shiga toxin-producing enterohemorrhagic E. coli (STEC) colitis may be complicated by life-threatening hemolytic-uremic syndrome (HUS) characterized by the triad of acute renal failure, hemolytic anemia, and thrombocytopenia [3, 4]. During previous STEC outbreaks, 0157:H7 serotype has been identified as the primary cause of colitis-associated HUS, which occurs primarily in children and is a rare event in adults [5, 6].

From May to June 2011, 3842 cases of infection with an unusual strain of Shiga toxin-producing E. coli, STEC 0104:H4, were reported during a nationwide outbreak in Germany and sprouts were finally identified as the most likely outbreak vehicle [7, 8]. The outbreak was characterized by several unusual features: a high incidence in adults (89\%), a greatly increased incidence of post-colitis HUS, a predominance of female patients, and the rare serotype 0104:H4. A total of 855 cases of HUS, including 36 (4.2\%) fatal cases, and 2987 additional cases of hemorrhagic STEC 0104:H4 colitis with 18 (0.6\%) fatal cases were reported. This marks one of the largest STEC outbreaks ever described worldwide and indicates a high virulence of the new serotype 0104: H4 [7, 9].

Recognition of infection during the outbreak 2011 was initially hampered by the lack of a specific laboratory approach [10]. Later on, the diagnosis was based on one-enzyme (Xbal) gel electrophoresis for confirmation of the outbreak strain [7]. The genome of the German outbreak strain 0104:H4 could be distinguished from other strains because it contains a distinct set of additional virulence and antibiotic-resistance factors $[9,10]$. In addition to the laboratory and clinical diagnosis of STEC infection, the assessment of gastrointestinal complications including colitis, toxic megacolon and colonic perforation are based on imaging. Early diagnosis and treatment are important to avoid fatal complications and to prevent dissemination of the infection to distant sites [11].

Computed tomography (CT) is widely used to assess patients with nonspecific abdominal pain or those suspected of having complications of colitis [12-14]. Therefore, radiologists must be familiar with E. coli colitis to assist in early diagnosis $[15,16]$. Clinical and epidemical findings of the E. coli outbreak in Germany of the 0104:H4 strain have been well described [7, 9, 17-19], but up to now there are no comprehensive reports of radiological findings of STEC 0104:H4 colitis. The purpose of this study was to determine abdominal CT and radiography features of STEC 0104: $\mathrm{H} 4$ colitis and to compare laboratory and clinical parameters in a cohort of consecutive patients affected during the outbreak in Germany in 2011.

\section{Materials and Methods}

\section{Patient population}

The local institutional review board approved the retrospective study and waived the requirement for written informed consent. Patients infected by STEC 0104:H4 and presenting with colitis or
HUS were defined as outbreak cases [7]. 270 patients with STEC 0104:H4 infection were treated at our university hospital during the outbreak between May and June 2011. 23 of these patients (8.5\%; 7 men, 16 women; mean age of $48 \pm 19$ years, range 18 83 years) underwent abdominal imaging and were included in this study. 12 patients received abdominal CT scanning and 11 patients received plain abdominal radiographs. The rationale for referral to radiological imaging was clinical evidence of severe gastrointestinal complications in all 23 cases.

\section{Clinical presentation and laboratory tests}

Medical records of all 23 patients were reviewed for laboratory parameters, such as hemoglobin, hematocrit, erythrocytes, leucocytes (WBC), platelets, urea, creatinine, C-reactive protein, and lactate dehydrogenase. All tests were performed within 24 hours of radiological imaging. The presence of bloody diarrhea (three or more blood-containing loose stools in a 24-h period) and the clinical diagnosis "acute abdomen" were recorded as well as the duration of hospitalization.

\section{Abdominal CT and radiography}

Abdominal CT scans were performed with a 256-slice MDCT (Brilliance iCT, Philips Healthcare, Best, The Netherlands) with the following parameters: gantry rotation time $330 \mathrm{~ms}$, collimation $128 \times 0.625 \mathrm{~mm}, 0.758$ pitch, tube voltage $120 \mathrm{kV}$, automated effective tube current ranging from $40-200$ eff. mAs. Raw data sets were reconstructed in a soft tissue kernel (B30f) with a slice thickness of $5 \mathrm{~mm}$. The scan range extended from the top of the diaphragm to the bottom of the pelvis. CT images were obtained within a single breath-hold in end-expiration and in a supine position. No patient received oral contrast. 10 of the 12 patients $(83.3 \%)$ received $120 \mathrm{ml}$ of nonionic contrast material with an iodine concentration of $300 \mathrm{mg} / \mathrm{ml}$ (Imeron $300^{\circledR}$, Bracco-Altana Imaging, Konstanz, Germany) administered in an antecubital vein at a rate of $2.5 \mathrm{ml} / \mathrm{s}$ via an 18-gauge peripheral intravenous catheter. Abdominal plain radiographs were performed in a supine and lateral position. Coverage included the top of the liver to the pubic symphysis.

\section{Image evaluation}

CT scans were assessed by two readers in consensus (with 5 and 7 years of gastrointestinal radiology experience) for the presence of colonic wall thickening as a radiological criterion for the presence of colitis. Based on the criteria from previous reports, an abnormal colonic wall thickness greater than or equal to $4 \mathrm{~mm}$ was defined as abnormal [20]. The colon was divided into four segments (ascending, transverse, descending and sigmoid), and any affected segment was noted. Involvement pattern was determined either as segmental or as pancolic. The presence and quantity of ascites (small, moderate, and large) was approximated. CT density measurements of ascites were performed to assess the presence of blood constituent $(\mathrm{HU}>40)$. The presence of pericolic stranding, colonic wall contrast enhancement, and stenosis was assessed. The presence, location and extent of colonic distension, air fluid levels, and free intra-abdominal air were assessed by CT scans and radiographs. A colon diameter greater than $6 \mathrm{~cm}$ was considered colonic distension.

\section{Statistical analysis}

Discrete variables are given as numbers and percentages, and continuous variables as means \pm standard deviation or means (95\% confidence intervals). The distribution of data was tested. 
Data not normally distributed were log transformed to reach normal distribution. Univariate analyses were performed using the Chi-square test for categorical variables and Student's t-test for continuous variables.

The McNemar test [21] was applied to determine whether wall thickening or pathologic colonic distension occurred more often in distinct colonic segments in comparison to other segments. Spearman correlation coefficient $r$ was used to investigate the correlation with laboratory parameters. A nominal p-value $<0.05$, two-tailed, was considered statistically significant. All statistical analyses were carried out using SAS 9.2 software.

\section{Results \\ $\nabla$}

\section{Study population}

Abdominal imaging was performed within $7.2 \pm 9.9$ days (range: 1 - 46 days) after hospitalization in all patients. The indications for referral to abdominal imaging were acute abdomen in 10 of the 23 patients (43.5\%), and the search for an infectious focus and/or free intra-abdominal air in the presence of critically elevated WBC or CRP in the remaining 13 patients (56.5\%). WBC was elevated in 20/23 patients (87.0\%) and CRP was elevated in 21/23 patients (95.7\%). Detailed results of laboratory parameters are listed in $\bullet$ Table 1. 22 patients (95.7\%) presented with bloody diarrhea at the time of imaging. During the further course of disease, $4 / 23$ patients $(17.4 \%)$ were diagnosed with toxic megacolon. 5 of the 23 patients $(21.7 \%$ ) underwent abdominal surgery due to their clinical condition. In one of these patients hemicolectomy was performed due to extensive segmental inflammation. In another patient subtotal colectomy was performed due to uncontrollable colonic bleeding. The remaining three patients underwent surgical abdominal exploration and lavage. One of the surgically explored patients and one diagnosed with toxic megacolon died during the course of disease $(2 / 23 ; 8.7 \%) .20$ of the 23 patients $(87.0 \%)$ were diagnosed with HUS and 19/23 (82.6\%) had to undergo plasmapheresis and/or dialysis. The mean hospitalization time was 25.7 \pm 12.6 days (range: 1 - 59 days).

\section{Radiological findings}

All of the 12 patients who underwent CT had abnormally thickened colonic wall segments ( Table 2). 9 of these 12 (75\%) had segmental wall thickening, and 3 patients (25\%) had pancolic involvement. The descending colon was predominantly affected (11/12 patients; $91.7 \%)$ and thickened significantly more often than the ascending colon ( $\mathrm{p}<0.001)$, transverse colon $(\mathrm{p}<0.001)$, or sigmoid colon $(\mathrm{p}<0.001)$. The maximal wall thickness ranged from $6-19 \mathrm{~mm}$ (mean: $10.4 \pm 4.5 \mathrm{~mm}$ ). Increased contrast enhancement of colonic wall segments was observed in $4 / 12$ patients (33.3\%). Extensive abnormal wall thickening with subtotal occlusion of the lumen and stenosis was observed in 3/12 patients (25\%). In all three cases the descending colon was involved with consecutive upstream dilatation of the transverse and ascending colon ( $\bullet$ Fig. 1). The upstream colonic dilatation was significantly higher $(p=0.012)$ in patients with stenosis than in the remaining study population $(82.0 \mathrm{~mm}$ [95\% CI, 65.7 - 98.3] vs. $55.9 \mathrm{~mm} \mathrm{[95 \%}$ CI, 46.5 - 65.3]). All 12 patients who received CT scanning had pericolic stranding around the affected segments.

Pathologic segmental colonic lumen distension was found in 16 of 23 patients (69.6\%) who underwent abdominal CT or plain radiographs. The ascending colon (11/23 patients; $47.8 \%)$ and transverse colon (12/23 patients; $52.2 \%)$ were dilated significantly more often $(\mathrm{p}=0.006$ and $\mathrm{p}=0.003$, respectively $)$ than the descending colon $(1 / 23 ; 4.3 \%$ ) (Fig. 02,3 ). The mean diameter of the maximal distended colonic lumen was of $64 \pm 18 \mathrm{~mm}$ (range $33-108 \mathrm{~mm}$ ). The extent of colonic lumen distension was significantly ( $\mathrm{p}=0.008)$ higher in patients with pathologic air-fluid levels $(83.8(95 \% \mathrm{CI}, 66.5-101.1) \mathrm{cm})$, which were present in 5 of 23 patients $(21.7 \%)$, than in patients without pathologic air-fluid levels (56.3 [95\% CI, $47.2-65.4] \mathrm{cm}$ ). Colonic lumen distension was significantly higher $(\mathrm{p}=0.0231)$ in patients with ascites $(67.1[95 \% \mathrm{CI}, 57.6-76.6] \mathrm{cm})$ than in patients without ascites (39.0 [95\% CI, $17.7-60.3] \mathrm{cm})$. Ascites was present in 10 of the 12 patients (83.3\%) undergoing CT. The quantity of ascites was considered small in $2 / 10$ patients $(20 \%)$, moderate in $5 / 10$ cases (50\%), and large in $3 / 10$ patients (30\%). None of these patients presented with bloody ascites. Free abdominal air was detected on plain abdominal radiography in one patient (4.3\%) who subsequently underwent abdominal surgery and hemicolectomy.

\section{Comparison of radiological findings, laboratory param-} eters and clinical parameters

In the initial comparison of radiological findings and clinical parameters, pathological lumen distension of the transverse colon was associated with reduced hemoglobin (difference: $1.9 \mathrm{~g} / \mathrm{dl}$ [0.07-3.9g/dl], p=0.059), hematocrit (difference: 6.4\% [0.5$12.4 \%], \mathrm{p}=0.047$ ), and erythrocytes (difference: $0.88 \times 10^{12 / 1}$ $\left.\left[0.12-1.64 \times 10^{12 / 1}\right), p=0.025\right)$. Moreover, pathologic lumen distension was higher (difference $31.5 \mathrm{~mm}$ [0.7-62.3 mm], p=0.046) in the two patients who died during the course of disease as compar-

Table 1 Results of relevant biochemical parameters. ${ }^{1}$

Tab. 1 Ergebnisse der relevanten Laborparameter.

\begin{tabular}{|c|c|c|c|c|c|}
\hline biochemical parameter & normal range & mean \pm SD & range & \multicolumn{2}{|c|}{$\begin{array}{l}\text { number of patients with abnormal } \\
\text { parameters (\%) }\end{array}$} \\
\hline - hemoglobin (g/dL) & $12.3-17.5$ & $9.7 \pm 2.4$ & $6.1-15.3$ & $21 / 23$ & $(91.3)$ \\
\hline - hematocrit (\%) & $35-48$ & $28.6 \pm 7.5$ & $18.6-45.0$ & $21 / 23$ & $(91.3)$ \\
\hline - erythrocytes $\left(\times 10^{12} / \mathrm{L}\right)$ & $4.1-5.9$ & $3.3 \pm 1.0$ & $2.1-5.9$ & $20 / 23$ & $(87.0)$ \\
\hline - leucocytes $\left(\times 10^{9} / \mathrm{L}\right)$ & $3.8-11.0$ & $19.9 \pm 7.9$ & $8.8-45.6$ & $20 / 23$ & $(87.0)$ \\
\hline - platelet count $\left(\times 10^{9} / \mathrm{L}\right)$ & $150-400$ & $139.4 \pm 112.8$ & $27-390$ & $15 / 23$ & $(65.2)$ \\
\hline - urea (mg/dL) & $8.0-26.0$ & $42.1 \pm 22.7$ & $7.0-86.0$ & $19 / 23$ & $(82.6)$ \\
\hline - creatinine (mg/dL) & $0.5-1.3$ & $3.1 \pm 2.1$ & $0.5-7.4$ & $19 / 23$ & $(82.6)$ \\
\hline - C-reactive protein (mg/L) & $<5$ & $93.6 \pm 68.9$ & $5.0-276$ & $21 / 23$ & $(91.3)$ \\
\hline$-\operatorname{LDH}(\mathrm{U} / \mathrm{L})$ & $135-225$ & $810.1 \pm 574.5$ & $186-2019$ & $22 / 23$ & $(95.7)$ \\
\hline
\end{tabular}

${ }^{1} \mathrm{LDH}=$ Lactate dehydrogenase. Percentages are presented as numbers in parentheses. 
Table 2 Specific imaging findings on abdominal CT $(n=12)$ and plain radiography $(n=11)$ in all 23 patients. Findings that were assessed only by $C T$ are listed below $(n=12){ }^{1}$

Tab. 2 Spezifische radiologische Befunde aller 23 Patienten, die sowohl auf den CT-Untersuchungen ( $n=12$ ) als auch auf den Abdomenübersichtsradiografien $(n=11)$ erhoben werden konnten. Darunter die Befunde, die nur mittels CT bestimmt werden konnten $(n=12)$.

\begin{tabular}{|lcr|}
\hline radiological finding & \multicolumn{2}{c|}{ number of affected patients (\%) } \\
\hline colon distension & $16 / 23$ & $(69.6)$ \\
\hline segmental distension & $16 / 23$ & $(69.6)$ \\
\hline pancolic distension & $0 / 23$ & $(0.0)$ \\
\hline - distended ascending c. & $11 / 23$ & $(47.8)$ \\
\hline - distended transversal c. & $12 / 23$ & $(52.2)$ \\
\hline - distended descending c. & $1 / 23$ & $(4.3)$ \\
\hline - distended sigmoid c. & $0 / 23$ & $(0.0)$ \\
\hline air-fluid levels & $5 / 23$ & $(21.7)$ \\
\hline free abdominal air & $1 / 23$ & $(4.3)$ \\
\hline colonic wall thickening & $12 / 12$ & $(100.0)$ \\
\hline segmental wall thickening & $9 / 12$ & $(75.0)$ \\
\hline pancolic wall thickening & $3 / 12$ & $(25.0)$ \\
\hline - thickened ascending c. & $3 / 12$ & $(25.0)$ \\
\hline - thickened transversal c. & $3 / 12$ & $(25.0)$ \\
\hline - thickened descending c. & $11 / 12$ & $(91.7)$ \\
\hline - thickened sigmoid c. & $3 / 12$ & $(25.0)$ \\
\hline mural contrast enhancement & $4 / 12$ & $(33.3)$ \\
\hline pericolic stranding & $12 / 12$ & $(100.0)$ \\
\hline stenosis & $3 / 12$ & $(25.0)$ \\
\hline ascites & $10 / 12$ & $(83.3)$ \\
\hline - ascites + & $2 / 12$ & $(16.7)$ \\
\hline - ascites ++ & $5 / 12$ & $(41.7)$ \\
\hline - ascites +++ & $3 / 12$ & $(25.0)$ \\
\hline
\end{tabular}

${ }^{1}$ Numbers in parentheses represent percentages.

ed to the remainder of the study population. However, the extent of pathologic lumen distension associated neither with the indication for abdominal surgery $(p=0.260)$ nor with the duration of hospitalization $(\mathrm{p}=0.512)$. Also, neither the indication for surgery nor the duration of hospitalization was associated with any other radiological findings.

\section{Discussion}

$\nabla$

Review of abdominal radiographic findings of 23 patients with STEC 0104:H4 colitis revealed a high incidence of abnormal wall thickening of the descending colon with pericolic stranding and upstream abnormal transverse and/or ascending colonic lumen distension. Two patients with a fatal course presented with massive distension of the transverse colon. However, no significant association between radiological findings and clinical parameters was found. One of the 23 patients underwent immediate surgery due to the presence of free abdominal air. The remaining 22 patients did not require immediate surgical intervention. Due to the high percentage of women in the STEC 0104:H4 population during the German outbreak 2011 [7, 18], 70\% of the patients in this study were female.

There is considerable overlap in the clinical appearance of various infectious types of colitis. They are usually confirmed clinically on the basis of stool and blood analyses and/or colonoscopy supported by biopsy results. All infectious types of colitis share the radiological features of wall thickening, pericolic stranding,
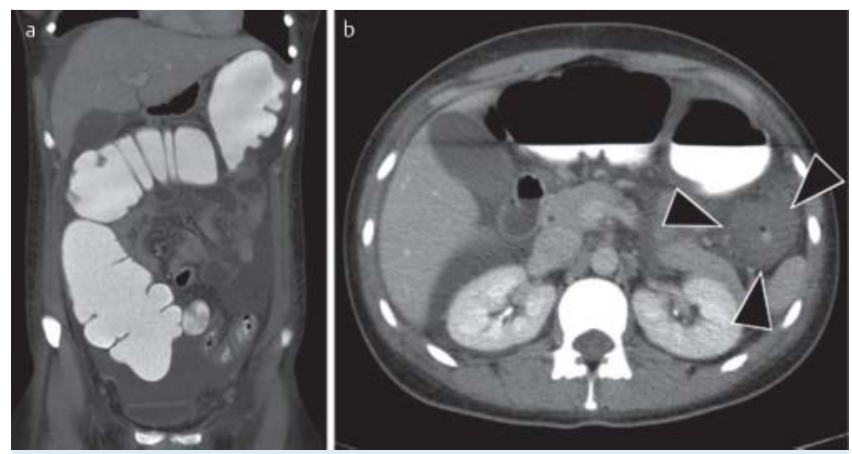

Fig. 1 Coronal $\mathbf{a}$ and axial $\mathbf{b}$ CT images of a 23-year-old female patient with STEC 0104:H4 colitis and HUS. The patient suffered from persistent diarrhea and received dialysis and plasmapheresis due to HUS. Seven days after hospitalization, the patient presented with severe abdominal pain. CT demonstrated ascites, dilatation (up to $88 \mathrm{~mm}$ ) of the ascending and transverse colon a with air-fluid levels and marked circumferential thickening (up to $18 \mathrm{~mm}$ ) of the descending colonic wall (b, arrowheads). The colonic lumen was filled with contrast material applied two days earlier for performing a gastrointestinal passage. The patient was diagnosed with toxic megacolon. However, no further specific treatment was initiated, the symptoms finally improved and the patient was discharged nine days after the $\mathrm{CT}$ examination.

Abb. 1 Koronare $\mathbf{a}$ und axiale $\mathbf{b}$ CT-Rekonstruktionen einer 23 Jahre alten Patientin mit STEC 0104:H4-Kolitis und HUS. Die Patientin litt unter persistierenden Durchfällen und wurde mittels Plasmapherese aufgrund von HUS therapiert. Sieben Tage nach der initialen Aufnahme traten schwere abdominelle Schmerzen auf. Die durchgeführte $\mathrm{CT}$ zeigt Aszites, Dilatation des aszendierenden und transversalen Kolons (bis $88 \mathrm{~mm}$ ) a mit Luft-Flüssigkeitsspiegeln und starker Wandverdickung (bis $18 \mathrm{~mm}$ ) des deszendierenden Kolons (b, Pfeilspitzen). Das Kolon ist noch mit Kontrastmittel einer zwei Tage zuvor durchgeführten Magen-Darm-Passage gefüllt. Es wurde die Diagnose eines toxischen Megakolons gestellt. Es wurde keine weitere spezifische Behandlung eingeleitet, dennoch verbesserte sich der Zustand und die Patientin konnte 9 Tage nach der CT-Untersuchung entlassen werden.

and various degrees of ascites [12 - 15]. In most infectious forms of colitis the distribution is contiguous or pancolic [12, 13, 22]. This is in contrast to the findings of this study, where the majority of patients presented with segmental involvement. Previous imaging studies of E. coli colitis reported contiguous involvement with the transverse colon being most often affected $[23,24]$. In contrast, this study revealed a predominance of descending colon wall thickening with abnormally distended but normal wall thickness of the transverse colon, likely due to the downstream constriction of the involved wall of the descending colon. Pseudomembranous colitis also demonstrates marked wall thickening, but can be clinically differentiated due to its association with broad-spectrum antibiotic treatment and the detection of clostridium difficile toxin in the stool. Neutropenic colitis is characterized by right-sided colonic and ileal involvement, which was never observed in the patients of this study with STEC 0104:H4 infection [12]. Diverticulitis can be discriminated, since the process is focal and asymmetric with fascial thickening and inflamed diverticula [25]. Hence, the presence of abnormal transverse and/ or ascending colonic lumen distension with a descending colon with wall thickening seems be a characteristic finding in patients with STEC 0104:H4.

The presence of ascites was observed in $>80 \%$ of the CT scans. This is an unspecific finding in all types of infectious colitis, but is rarely associated with ulcerative colitis and Crohn's disease 


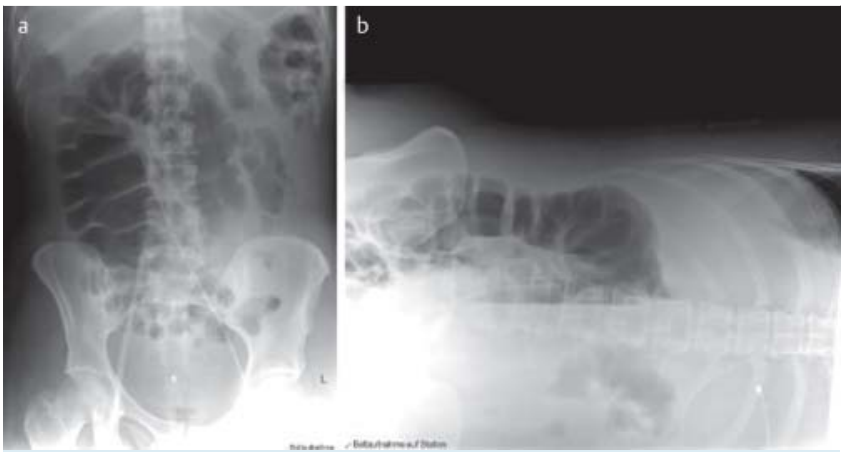

Fig. 2 Supine view $\mathbf{a}$ and left lateral decubitus view $\mathbf{b}$ of an abdominal radiograph of a 31-year-old female patient with STEC O104:H4 colitis and hemolytic-uremic syndrome. The patient presented with ulcerating and hemorrhagic colitis and was treated with dialysis and plasmapheresis for 1 month. Abdominal radiography a, $\mathbf{b}$ demonstrated dilatation of the ascending and transverse colon with air-fluid levels. The patient was diagnosed with toxic megacolon. Due to extensive hemorrhagic diarrhea, repeated blood transfusions were administered and subtotal colectomy was performed two weeks later. After two months of hospitalization, the patient was discharged in a healthy state.

Abb. 2 Abdomenübersicht in Rückenlage a sowie in Linksseitenlage b einer 41 Jahre alten Patientin mit STEC 0104:H4-Kolitis und HUS. Die Patientin litt an einer ulzerierenden und hämorrhagischen Kolitis und wurde über einen Monat mittels Dialyse und Plasmapherese behandelt. Die Abdomenaufnahmen $\mathbf{a}$, $\mathbf{b}$ zeigen eine massive Dilatation des aszendierenden und transversalen Kolons mit Luft-Flüssigkeitsspiegeln. Es wurde die Diagnose eines toxischen Megakolons gestellt. Aufgrund der massiven hämorrhagischen Durchfälle mussten wiederholt Bluttransfusionen durchgeführt werden und 2 Wochen später eine subtotale Kolektomie durchgeführt werden. Nach insgesamt 2 Monaten Krankenhausaufenthalt konnte die Patientin geheilt entlassen werden.

[12]. Increased contrast enhancement of the colonic wall was observed in a minority of patients and no specific pattern was identified. The degree of bowel wall thickening is said to aid in the differential diagnosis of colonic disease $[14,26]$. However, the maximal bowel wall thickening ranged from 6 to $19 \mathrm{~mm}$ in this study population, which seems to preclude establishing a specific diagnosis based on the degree of colonic wall thickening alone. Patients with hemorrhagic E. coli colitis are at increased risk for HUS and other severe complications. Therefore, it is crucial to diagnose the disease promptly. The list of differential diagnoses for E. coli colitis includes appendicitis, ischemic colitis, inflammatory bowel disease, as well as infectious colitis due to Shigella, salmonella, Campylobacter, Clostridium difficile or cytomegalovirus $[12,13,23]$. Diagnostic imaging is generally not required for the differential diagnosis of E. coli colitis. The diagnosis is classically established by clinical and laboratory findings. However, the nature of abdominal pain is nonspecific, and abdominal imaging is ordered for its evaluation. Moreover, the spectrum of illness associated with E. coli colitis is broad and may range from asymptomatic infection to hemorrhagic colitis and can rapidly progress to HUS, a life-threatening condition [3, 23]. Hence, not all patients with STEC 0104:H4 colitis present with classic symptoms such as cramps and hemorrhagic diarrhea, but rather with generalized constitutional symptoms, constipation or even an acute abdomen [2]. In these patients specific radiological findings could lead to correct diagnosis and appropriate patient management. Clinical history and laboratory testing are critical to exclude other colitides that may mimic STEC 0104:H4 colitis. However, the purpose of this retrospective study was not to as-

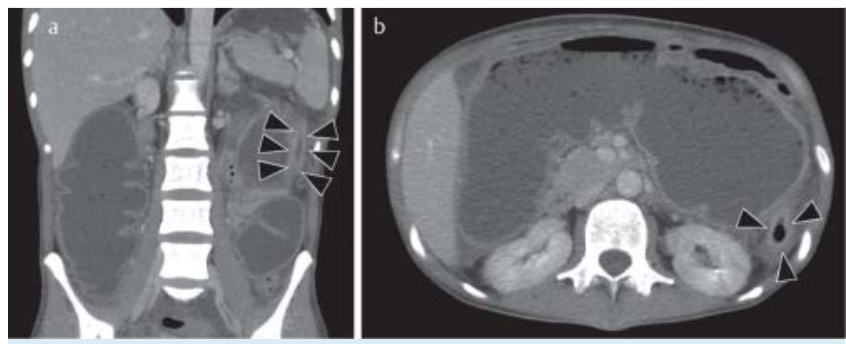

Fig. 3 Coronal a and axial b CT images of a 41-year-old female patient with STEC 0104:H4 colitis. The patient initially presented with hemorrhagic colitis. Two weeks after hospitalization, CT demonstrated massive dilatation (up to $81 \mathrm{~mm}$ ) of the ascending and transverse colon a, b. The descending colon showed a normal lumen diameter but circumferential thickening (up to $10 \mathrm{~mm}$ ) of the colonic wall (a, b, arrowheads). One week after the $\mathrm{CT}$, the patient suffered from acute and severe abdominal pain and abdominal radiography (not shown) demonstrated free abdominal air and massive dilatation of the ascending and transverse colon. The patient was diagnosed with toxic megacolon and underwent hemicolectomy. Finally, after 6 weeks of hospitalization, the patient was discharged in a healthy state.

Abb. 3 Koronare $\mathbf{a}$ und axiale $\mathbf{b}$ CT-Rekonstruktionen einer 41 Jahre alten Patientin mit STEC 0104:H4-Kolitis. Die Patientin wurde initial wegen einer hämorrhagischen Kolitis aufgenommen. Zwei Wochen nach der Aufnahme zeigt das CT eine massive Dilatation (bis $81 \mathrm{~mm}$ ) des aszendierenden und transversalen Kolons a, b. Das deszendierende Kolon zeigt einen normalen Lumendiameter, aber eine zirkuläre Wandverdickung (bis auf $10 \mathrm{~mm}$ ) (a, b, Pfeilspitzen). Eine Woche nach der CT traten massive abdominelle Schmerzen auf und die daraufhin durchgeführte Abdomenübersicht (nicht gezeigt) zeigte freie intraabdominelle Luft sowie eine massive Dilatation des aszendierenden und transversalen Kolons. Es wurde ein toxisches Megakolon diagnostiziert und eine Hemikolektomie durchgeführt. Nach 6 Wochen konnte die Patientin geheilt entlassen werden.

sess the value of abdominal CT or radiography for aiding the diagnosis of an infection with SO104:H4, but rather to define abdominal radiological findings in these patients. Increased radiologist awareness of STEC 0104:H4 colitis will expand the differential diagnosis in patients with suspected colitis and prevent inappropriate medical or surgical treatment.

The patients with STEC 0104:H4 colitis during the outbreak in 2011 were most often treated medically by supportive measures directed toward maintaining hydration and electrolyte balance. Hence, abdominal imaging played a prominent role in excluding the need for immediate surgical intervention in severe cases. In only one of the 23 studied patients abdominal imaging revealed free abdominal air and immediate surgical treatment including hemicolectomy was initiated. In all other cases surgical interventions were performed days later, based on worsening of clinical symptoms and progressive system deterioration.

Due to its retrospective nature, there are inherent limitations to this study. Only $8.5 \%$ of all E. coli 0104:H4-positive patients treated in our institution during the outbreak 2011 underwent abdominal imaging. Only severely affected cases were referred to abdominal CT or radiography which leads to a potential selection bias. Of note, only one patient underwent immediate surgery after imaging. Moreover, this was an observational study, and nominal p-values without adjustment for multiplicity are reported. The study was not powered for a multitude of statistical tests. Although we identified characteristic diagnostic findings for $\mathrm{E}$. coli 0104:H4 colitis, the only way to determine the exact clinical impact of abdominal imaging would be a prospective study with colonoscopy as the gold standard for the exact assessment of in- 
flammatory changes, and newer imaging modalities including CT colonography and diffusion-weighted magnetic resonance imaging with the measurement of multiple clinical and radiological parameters [27 - 30]. However, practical considerations preclude such a study.

In summary, the main finding observed in all CT scans of hospitalized patients with E. coli 0104:H4 colitis was abnormal wall thickening of the descending colon with pericolic stranding and upstream abnormal transverse and/or ascending colonic lumen distension. While thickening of the descending colonic wall may be seen as a nonspecific sign, the combination with massive upstream dilatation of the transverse and/or ascending colonic lumen can be used to narrow down the differential diagnosis. The final diagnosis concerning the type of colitis is based on clinical and laboratory data, but recognizing specific abdominal imaging features helps to narrow down the differential diagnosis. In conclusion, in the presence of abnormal radiological findings with the proper clinical history, abdominal imaging can aid the diagnosis of E. coli O104:H4 colitis and may prevent unnecessary medical or surgical treatment in possible future outbreaks.

\section{Affiliations \\ ${ }^{1}$ Diagnostikzentrum, Klinik und Poliklinik für Diagnostische und Interventio- nelle Radiologie, Universitätsklinikum Hamburg-Eppendorf, Hamburg \\ ${ }^{2}$ I. Medizinische Klinik, Universitätsklinikum Hamburg-Eppendorf, Hamburg \\ 3 Institut für Biometrie und Epidemiologie, Universitätsklinikum Hamburg- Eppendorf, Hamburg \\ ${ }^{4}$ III. Medizinische Klinik, Universitätsklinikum Hamburg-Eppendorf, Hamburg}

\section{References}

1 Kaper JB, Nataro JP, Mobley HL. Pathogenic Escherichia coli. Nat Rev Microbiol 2004; 2: 123-140

2 Riley LW, Remis RS, Helgerson SD et al. Hemorrhagic colitis associated with a rare Escherichia coli serotype. N Engl J Med 1983; 308: 681 685

3 Neill MA, Agosti J, Rosen H. Hemorrhagic colitis with Escherichia coli 0157:H7 preceding adult hemolytic uremic syndrome. Arch Intern Med 1985; 145: 2215 - 2217

4 Gasser C. Hemolytic disease of the newborn due to ABO groups. Rev Hematol 1955; 10: 253-254; discussion 256-264

5 Tarr PI, Gordon CA, Chandler WL. Shiga-toxin-producing Escherichia coli and haemolytic uraemic syndrome. Lancet 2005; 365: 1073-1086

6 Karpac CA, Li X, Terrell DR et al. Sporadic bloody diarrhoea-associated thrombotic thrombocytopenic purpura-haemolytic uraemic syndrome: an adult and paediatric comparison. Br J Haematol 2008; 141: $696-707$

7 Frank C, Werber D, Cramer JP et al. Epidemic profile of Shiga-toxin-producing Escherichia coli 0104:H4 outbreak in Germany. N Engl J Med 2011; 365: 1771 - 1780

8 Buchholz U, Bernard H, Werber D et al. German outbreak of Escherichia coli 0104:H4 associated with sprouts. N Engl J Med 2011; 365: 1763 1770
9 Rasko DA, Webster DR, Sahl JW et al. Origins of the E. coli strain causing an outbreak of hemolytic-uremic syndrome in Germany. N Engl J Med 2011; 365: 709-717

10 Rohde H, Qin J, Cui Y et al. Open-source genomic analysis of Shiga-toxin-producing E. coli 0104:H4. N Engl J Med 2011; 365: 718 - 724

11 Kuijper EJ, Soonawala D, Vermont C et al. Household transmission of haemolytic uraemic syndrome associated with Escherichia coli 0104: H4 in the Netherlands, May 2011. Euro Surveill 2011; 16: 19897

12 Thoeni RF, Cello JP. CT imaging of colitis. Radiology 2006; 240: 623 638

13 Philpotts LE, Heiken JP, Westcott MA et al. Colitis: use of CT findings in differential diagnosis. Radiology 1994; 190: 445-449

14 Horton KM, Corl FM, Fishman EK. CT evaluation of the colon: inflammatory disease. Radiographics 2000; 20: 399-418

15 Markose G, $\mathrm{Ng}$ CS, Freeman AH. The impact of helical computed tomography on the diagnosis of unsuspected inflammatory bowel disease in the large bowel. Eur Radiol 2003; 13: 107-113

16 Peterson RB, Meseroll WP, Shrago GG et al. Radiographic features of colitis associated with the hemolytic-uremic syndrome. Radiology 1976; 118: $667-671$

17 Colic E, Dieperink H, Titlestad K et al. Management of an acute outbreak of diarrhoea-associated haemolytic uraemic syndrome with early plasma exchange in adults from southern Denmark: an observational study. Lancet 2011; 378: 1089-1093

18 Scheutz F, Nielsen EM, Frimodt-Moller J et al. Characteristics of the enteroaggregative Shiga toxin/verotoxin-producing Escherichia coli 0104:H4 strain causing the outbreak of haemolytic uraemic syndrome in Germany, May to June 2011. Euro Surveill 2011; 16: 19889

19 Greinacher A, Friesecke S, Abel P et al. Treatment of severe neurological deficits with IgG depletion through immunoadsorption in patients with Escherichia coli 0104:H4-associated haemolytic uraemic syndrome: a prospective trial. Lancet 2011; 378: 1166-1173

20 Ros PR, Buetow PC, Pantograg-Brown L et al. Pseudomembranous colitis. Radiology 1996; 198: 1 -9

21 McNemar $Q$. Note on the sampling error of the difference between correlated proportions or percentages. Psychometrika 1947; 12: 153157

22 Macari M, Balthazar EJ. CT of bowel wall thickening: significance and pitfalls of interpretation. Am J Roentgenol 2001; 176: 1105-1116

23 Miller FH, Ma JJ, Scholz FJ. Imaging features of enterohemorrhagic Escherichia coli colitis. Am J Roentgenol 2001; 177: 619-623

24 Shortsleeve MJ, Wilson ME, Finklestein $M$ et al. Radiologic findings in hemorrhagic colitis due to Escherichia coli 0157:H7. Gastrointest Radiol 1989; 14: 341 - 344

25 Chintapalli KN, Chopra S, Ghiatas AA et al. Diverticulitis versus colon cancer: differentiation with helical CT findings. Radiology 1999; 210: $429-435$

26 Balthazar EJ. CT of the gastrointestinal tract: principles and interpretation. Am J Roentgenol 1991; 156: 23-32

27 Schwartz CA, Haage P, Hohl C. Experimental early detection of acute mesenteric ischemia with functional MRI (DWI) and parallel imaging. Fortschr Röntgenstr 2012; 184: 520-526

28 Mang T, Schima W, Brownstone E et al. Consensus statement of the Austrian Society of Radiology, the Austrian Society of Gastroenterology and Hepatology and the Austrian Society of Surgery on CT colonography (Virtual Colonoscopy). Fortschr Röntgenstr 2011; 183: 177-184

29 Heiss $P$, Wrede CE, Hamer OW et al. Multidetector computed tomography mesentericography for the diagnosis of obscure gastrointestinal bleeding. Fortschr Röntgenstr 2011; 183: 37-46

30 Klasen J, Antoch G, Blondin D. MR imaging of the abdomen in pregnancy. Fortschr Röntgenstr 2011; 183: 514-522 